\title{
An Evaluation of Karl Barth's Encounter Revelation and the View of God
}

\author{
*Alexander Mwita \\ Assistant Lecturer of Systematic Theology \\ University of Arusha, Tanzania \\ *Corresponding author: mwitaa@aua.ac.ke
}

\begin{abstract}
This paper aimed at evaluating Karl Barth's theology of encounter revelation and the view of God in relation to the Christian theology of the knowledge of God. It employed literary approach of research that involves bibliographic data in four sections. The first section discussed a brief history of Karl Barth. The second section is an overview of the doctrine of revelation, both general and special revelation. Section three discussed Karl Birth's view of God in the context of encounter revelation. The fourth section evaluated Karl Barth's view of encounter revelation in relation to the knowledge of God. This study concluded that the encounter revelation is not the only way of knowing God. Though God reveals Himself fully through the person of Jesus Christ, He also reveals Himself in through general (Universal) and special (particular) revelation.
\end{abstract}

Key words: Revelation, Encounter Revelation, Knowledge of God, General Revelation, Special Revelation

\section{Introduction}

Knowing God does not depend on finite human search of God, but God reveals Himself to humanity through general and special revelations (Erickson' 2013). According to Marbaniang (2019), Karl Barth opines that there are two concepts of knowing God, anthropological concept and Christological concept. Anthropological concept is centered on a humanistic measure of all things and therefore is insufficient to grasp the knowledge of God. The Christological concept is centered on Jesus Christ to whom alone revelation of God to humanity depends and besides Christ, humanity cannot know God. This view led Barth to develop a theology of encounter revelation, whereby he rejects the Bible as the word of God but a mere record of revelation. He opines that the Bible was written by humans; therefore it is a witness to the word of God, the incarnate God (Barth, 1957).

Karl Barth's view of encounter revelation raises critical questions. First, does the theology of encounter revelation overlook the work of the Holy Spirit in biblical authorship? Second, if God's revelation is only through the person of Jesus Christ, how did God reveal himself before the time of the incarnation? This paper aims to evaluate Karl Barth's theology of encounter revelation in relation to the Christian theology of the knowledge of God. This discussion is divided into four sections. The first section discusses a brief history of Karl Barth. The second section is an overview of the doctrine of revelation, both general and special revelation. Section three discusses Karl Birth's view of God in the context of encounter revelation. The fourth section evaluates Karl Barth's view of encounter revelation in relation to the knowledge of God.

\section{A Brief History of Karl Birth}

Karl Barth was a Swiss theologian born in 1886. His father Fritz Barth was a professor at a Reformed seminary (Hutabarat, 2015). Encyclopedia Britannica (2010) informs that Barth received his formal education at an early age, and was confirmed to the Reformed church at the age of sixteen. He received his theological training at the universities of Bern, Berlin, Tübingen, and Marburg under the influence of liberal theology of Adolf Harnack, Wilhelm Herrmann and Friedrich Schleiermacher. 
Karl Barth later challenged the liberal ideologies of rationalism and dualism and embraced the reality of Jesus's resurrection after a comprehensive study of the Pauline Epistle to the Romans under the influence of a Moravian scholar Christopher Blumhardt. This shift changed his views of divine revelation which shaped his interpretation of the scripture expressed in the collection of his sermons which were collected under the title The Word of God and the Word of Man. This was a reaction against liberal theology in an attempt to revive orthodoxy. Therefore, his theology has been known as neo-orthodoxy (Hutabarat, 2015).

In his first scholarly publication entitled The Epistle to Romans, Barth described how the infinite God can be known by finite humanity. McCormack (1997) concluded that, "Barth's concern was to find out how God could be known by human beings without ceasing to be God, to be the master of the revelation between God and humans?" (p.207). This inquiry led him to a further scholarship of systematic theology whereby he developed a view of the word of God concluding that the person of Jesus Christ qualifies to be the word of God witnessed by the scriptures (Smith, 1992). He published a major work in systematic theology entitled Church Dogmatics in four volumes of which his views reflect liberal influence of the authority of the Canon. Hutabarat (2015) comments that "for Barth, the Bible is human document and fallible and the historicity of the Scripture is unimportant and it is not God's Word in the sense that Jesus Christ is the very Word of God, for He is God Himself in action and communication. The Bible is one form of God's Word, not the primary but a secondary form" (p. 125). Despite Barth's challenge to liberal theology, his concept of biblical authority reflects the rationalism of his former professors.

\section{Revelation}

Revelation is a word that takes its root from the Latin word 'revelare' which means to uncover the hidden things. In theological scholarship, revelation depicts God's act of making Himself known to humanity for the purpose of creating a saving relationship with them.

Scripture reads "Let not the wise man boast of his wisdom or the strong man boast of his strength or the rich man boast of his riches, but let him who boasts boast about this: that he understands and knows me that I am the LORD, who exercises kindness, justice and righteousness on earth, for in these I delight, declares the LORD. (Jeremiah 9:2324). It also reads "Now this is eternal life: that they may know you, the only true God, and Jesus Christ, whom you have sent." (John 17:3)

These texts show that God desires to reveal Himself to all humanity so that all may know Him and enter into His saving relationship. In this case, revelation takes more than one channel because humans do not have identical opportunity for the knowledge of God. The Bible informs that;

indeed, when Gentiles, who do not have the law, do by nature things required by the law, they are a law for themselves, even though they do not have the law, since they show that the requirements of the law are written on their hearts, their consciences also bearing witness, and their thoughts now accusing, now even defending them (Romans 2:14, 15)

In the same vain, Dederen (2000) comments that "God reveals Himself in words and acts, through many different channels" (p. 23). Revelation, therefore, is divided into General and Special revelations.

\section{Biblical Response to General and Special Revelation}

This section highlights on biblical response to the two major types of revelation namely general and special revelations:

\section{General Revelation}

General revelation portrays God's self-disclosure through the natural world. Scripture such as Psalm 8:3; 19:1-4, 33:6-9; Romans 1:19-23; 2:14, 15 inform that God can be known by everyone through his creation and human conscience. Dederen (2000) defines it as a "revelation of God that is universal, accessible to all human beings everywhere, by whom God is known as Creator, Sustainer and Lord of the entire universe. As far as humanity is concerned, this general revelation is both external and internal; it is also inescapable" (p. 26). Therefore, general revelation is experienced in nature by all humanity (Grudem, 1994). This experience is manifested in the creation of God and the conviction of moral obligation of right and wrong. 
In the face of different views of General revelation, nature, moral conscience and history have been generally accepted as modalities of God's selfdisclosure (Dederen, 2000). Nature submits that the universe reveals its designer as God. The harmonious existence of the universe convinced the Psalmist to focus his praise to the creator as recorded in Psalm 19:1 that the heavens declare the glory of God and the firmament shows His handiwork. Erickson (2013) comments that "General revelation is most frequently thought in connection with the amazing and impressive character of the creation, which seems to point to a very powerful and wise person who is capable of designing and producing intricate variety and beauty" (p. 154).

Moreover, Scripture reveals that humanity has no excuse for the ignorance of the power and existence of God because the natural world reveals his majesty (Romans 1:19-20). The natural phenomenon of ten plagues in Egypt (Exodus 7:112:32), for instance, acted as an object lesson of God's majesty to the Egyptians as well as to the Israelites. The antediluvian flood (Gen 6) and draught (1Kings 17) in the time of King Ahab reveal God's wrath against wickedness. Jonah had a positive response to the missionary call of God through the natural world (Jonah 1, 2). Therefore, creation gives a witness to God's existence, majesty, morality, kindness and transcendence.

Another modality of general revelation is the moral conscience. God explicitly declared that he writes his moral laws in the hearts of human beings (Romans 2:14, 15). This process reveals that human beings disclose moral qualities that reveal the image of God (Gen 1:26; Psalms 139:4) and these qualities give humanity the ability to make moral judgments of right and wrong because the natural knowledge of God has been put in the human conscience. Dederen (2000) comments "that the main task of conscience is to encourage us to do right and to avoid wrong" (p. 58). This encouragement suggests human religiosity. This religiosity is revealed in Paul's speech in Athens, "Men of Athens, I perceive that in all things you are very religious" (Act 17:22) confirming this desire of seeking God from the inner being. Erickson (2013) comments that;

in all cultures at all times and places, humans have believed in the existence of a higher reality than themselves and even of something higher than the human race collectively. While the exact nature of the belief and worship practice varies considerably from one religion to another, many see in this universal tendency toward worship of the holy the manifestation of a past knowledge of God, an internal sense of deity, which, although it may be marred and distorted, is nonetheless still present and operating in human experience (p. 155).

The last modality of general revelation is History. God's redemptive purpose can be traced in the historical events such as the Exodus and the Babylonian captivity which reveal God's love and wrath to those who disobey his statutes and directions. Erickson (2013) comments that "If God is at work in the world and is moving toward certain goals; it should be possible to detect the trend of his work in events that occur as part of history" ( $p$. 154). This idea can be traced in Paul's statement in the book of first Corinthians, as he says;

moreover, brethren, I do not want you to be unaware that all our fathers were under the cloud, all passed through the sea, all were baptized into Moses in the cloud and in the sea, all ate the same spiritual food, and all drank the same spiritual drink. For they drank of that spiritual Rock that followed them, and that Rock was Christ. But with most of them, God was not well pleased, for their bodies were scattered in the wilderness. Now, these things became our examples, to the intent that we should not lust after evil things as they also lusted (1Cor 10:1-6 NKJ).

These events reveal that God is directly engaged in human affairs and deliberate ignorance of these events is considered as denying God's revelation. The history, therefore, acts as a warning so that humanity may not repeat the same mistakes.

From general revelation and its modalities, classical philosophy constructs a natural theology which assets that nature and human conscience (reason) can lead to the knowledge of God apart from the Bible. Natural theology led philosophers to emphasize reason and wisdom as the channel of the knowledge of God. Natural theology further claims that it is possible to come to the genuine knowledge of God without relying upon any special authority of the church and of the Bible. This idea overlooks the fact that $\sin$ affected humanity and therefore unbelief causes the mind and reason of human 
being to become unreliable and require the guidance of the Holy Spirit to understanding the truth (Rom 1:21-22 NIV). In this case, understanding of General revelation should be affirmed by the Scripture.

\section{Special revelation}

Special revelation is another kind of God's revelation for the purpose of redemption of humanity. He does this through visions, angels, prophets, apostles and Jesus Christ is the center of which scripture becomes the record of the whole process. Dederen (2000) defines it as how God continues to reveal Himself through the Scripture, through the power and conviction of the Holy Spirit and through the mission of the church to all nations on earth.

These definitions give insights that special revelation comes to humanity as a clarification of general revelation. It is a redemptive call to enter into a personal relationship with God. In the beginning God had a direct encounter with the first human being (Gen 3:8 NKJ) but after sin, humanity lost this privilege and the relationship between God and humanity broke. Therefore, God planed other channels of revealing Himself to restore the broken relationship.

Erickson (2013) comments that "When sin entered the human race, however, the need for special revelation became more acute" (p. 177). Special revelation goes beyond general revelation for it answers epistemological questions, human values, the plan of salvation and eschatological concerns. This information is not revealed in the general revelation (natural world). The nature of special revelation includes;

1. Personal disclosure to some selected individuals. Through theophany, God appeared to Abraham, Isaac, Jacob and other prophets, purposely to make his will known to humanity and proclaim his redemptive love and mercy.

2. Accommodation of fallen human nature. In fulfilling his will to humanity, God condensed his divine message to the level of fallen human nature so that it could be understood. However, the process itself remained divine. This accommodation also includes the incarnation where the divine person of the Godhead became flesh, Jesus the Son of God.
3. Interconnectedness of the divine message in diversity and its progressive nature. Divine message came to different individuals of different cultures in different times with correctness of its intent and covers universal concern of human redemption.

Moreover, the divine wisdom decided to employ modes in which fallen humanity could grasp the divine message. These include the history of Israel, the life ministry, death and resurrection of Jesus Christ and the written word of God. Dederen (2000) affirms that;

The Special revelation is the entire process by which God has revealed Himself and His redemptive purpose for the human race to and through Israel, the prophets, apostles, but supremely in Jesus Christ. It is also how He continues to reveal Himself through the Scriptures under the illuminating and convicting power of the Holy Spirit and through the proclamation of the church to all nations on earth (p. 30).

This affirmation explicitly indicates that God has provided every possible way for him to be known by every individual on earth for $\mathrm{He}$ wishes that all might come to His loving relationship. This process traces its initial process immediately after the fall, and through different expedients, God's will and purpose can be understood by everyone in different periods.

\section{Karl Barth's Encounter Revelation}

Neo-orthodoxy theology of Karl Barth was invented by the ideology of encounter revelation. This ideology claims that Jesus Christ is the only revelation of God in place Scripture which is considered as a witness to the word of God (Gulley, 2003). This view was a reaction to the liberal theology which was against traditional orthodoxy (Smith, 1992). The main agenda of encounter revelation was to refute the liberal ideology of natural theology. Smith (1992) comments that "Bath claimed that it does not lead to the knowledge of God but rather to the religion of which man becomes the subject. Barth rejected the liberal ideology of reason as the basis of Knowing God. He viewed that apart from God self-revelation through Christ, man cannot know God for God is Wholly Other" (p. 28). According to Mueller (1972), Barth views revelation as not an intangible phenomenon 
but a concrete knowledge of God and humanity through the initiative of a sovereign God in the person of Jesus Christ. For him, the content of the image of God (Imago Dei) in humanity is not realistic and conclude that fallen humanity has no capacity of knowing God "finitum non capax infiniti" (Barth, 1960).

\section{Historical Overview of Encounter Revelation}

The initial step to encounter revelation is traced from World War 1 (1914-1918). Barth's liberal professors were among intellectuals who supported a statement of the war policy. He was displeased by their conduct and he tossed away their theology and concluded that future theology is hopeless (Barth, 1964). Barth became disappointed with liberal Protestantism when his mentors publicly supported the Kaiser's war policy in 1914. The war brought distraction and the expectation of liberal theology failed. Therefore, Europe experienced fear and crisis (Dreyer, 2017; Hardy, 2005).

In 1914, Barth left liberal theology and consecrated his scholarship to studying the Bible especially Pauline letters in an attempt to find out an alternative for liberal theology. He aimed to trace back traditional interpretation of the biblical doctrine of which his efforts came up with neoorthodoxy theology. This labeled him as the greatest theologian whose theology went beyond Protestant Liberalism (Holmes, 2018). His study focused on the sovereignty of God and the person of Jesus Christ. He released his first edition of the publication entitled Der Römerbrief presented as commentary on the epistle to the Romans. In this volume, Barth, on one hand, expressed his ideas against the war policy of Wilhelm II, the liberal secularism and modernism. On the other hand, he explained that the sovereign God and the plan of salvation cannot be controlled or possessed by human beings. Therefore, he concluded that human reason, history or morality cannot grasp the knowledge of God (McCormack, 1997).

In liberal theology, human psyche ideology of Schleiermacher, human history of Ernst Troeltsch and morality of Albrecht Ritschl were considered as initial point of theological study. Barth's publication challenged these ideas and proposed that theological study is possible because God reveals himself through incarnation; therefore, the knowledge of God depends on God's self-revelation. He confirmed his theology by saying "We can only speak of and with God because God spoke to us" (Barth, 1976, pp.1-2). Barth's argument against liberal theology and his argument for the sovereignty of God as presented in Der Römerbrief were modified in his major work of Systematic theology entitled Church Dogmatics. In these works, the theology of the Word of God is presented in three-folds modalities (Jesus Christ, the church, and Scripture).

\section{Views of God and Jesus Christ as a Revelation}

Barth's theological work is based on avoiding liberal theology which employs philosophical epistemology. He narrowed to studying Scripture as witness to Jesus Christ as God's Word. He concluded that knowing God is confined in God's Word (Jesus Christ) which makes God to be transcendent 'Wholly Other' and unknowable apart from Jesus Christ. On the transcendent part, Barth makes God to be isolated from His creation and therefore human being can not know God until God reveals Himself through His Word (Jesus Christ).

According to Smith (1992), God in Barth's view is hidden and mysterious and no human may know him. Confirming on the transcendent God, Barth (1939) declared that "God is above us, above space and time, above all concepts, opinions and all potentialities" (p. 28). Commenting the idea of unknown God, Barth (1933) in his commentary, Epistle to the Romans declared that "Man can never know God: man's wishing, seeking and striving are all in vain, the revelation that comes to human being through Jesus makes God to become a mystery, makes Himself known as the unknown, speaks as the eternally silent One" (p. 315). In Barth's view, God is unknowable by the finite, for he declares that revelation of God comes to humanity through the person of Jesus Christ. To him revelation becomes God's choice and humanity can do nothing in knowing God apart from the revelation in the crucified and the risen Jesus Christ.

With respect to Barth's view of revelation, Marbaniang (2019) reports that "Only in the incarnation does one encounter the Word of God as the Revelation of God Himself. The knowledge of God is grounded in God himself, not in nature, history or human words" (p. 7). In this sense, a general revelation from the creation, historical accounts of God's dealings with the human race and the image of God (Imago Dei) in humanity have no value in revealing God to human beings. This view, 
therefore, does not focus on the historical Jesus Christ, but the Christ of Faith. In this case, the historical life of Jesus Chris which includes His teachings, His views of Scripture and His moral life are rejected by the claims that they are the product of the sinful human mind.

This view tries to separate the historical life of Jesus and the historical event of death and resurrection because the focus is confined in a proclamation on Christ who was crucified and risen (Barth, 1856). For Barth, human knowledge cannot be trusted; therefore historical life of Jesus is invalid because it results from the inversion of the sinful human mind.

\section{Evaluation of Karl Barth's Encounter Revelation}

Encounter revelation rejects the general revelation and endorses only special revelation which is confined in the person of Jesus Christ, apart from whom human being cannot know God. Even in special revelation, Barth rejects scripture as the Word of God but a mere record and a witness to the Word of God (Jesus Christ). Smith (1992) quotes Barth's major work of Church Dogmatics saying that Barth advocates that human writers of the Bible speak as fallible and erring men, and from this concept Smith asks that, "if the Bible writer speaks as fallible and erring men how does the Bible possess authority?" (p. 29). This notion raises the critical questions stated in the introduction.

The first question asked is, is the theology of encounter revelation overlooked the work of the Holy Spirit in biblical authorship? Evaluating Barth's idea of encounter revelation concerning the question, two apologetic concerns come to the forefront. First, if biblical writers speak as fallible and erring men, why did he rely on Pauline epistle to develop his theology as it is presented in the Der Römerbrief? Why did he trust Apostle Paul who wrote and spoke as a fallible and erring man as he claimed in his work Church Dogmatics? Second, how can his theology of encounter revelation be trusted for he also speaks as a fallible and erring man? These two concerns reveal that, Barth ignored the inspiration motif of the Scripture (2 Tim 3:16,17; 2 Pet 1:20,21). Biblical writers did not speak like fallible and erring men as Barth claimed, but rather spoke as they were moved by the Holy Spirit. In this case, Scripture is not a mere witness to the Word of God but a revelation, for it contains the spoken word of God in declaring and expounding general revelation (Gulley, 2003).

Barth's rejection of liberal theology led him to the extreme, to a non-cognitive epistemology. At the same time, he went back to the historical-critical method of the liberal theologians which consider the Bible as a human document subject to criticism. Therefore, encounter revelation theology lacks consistency and cognitive proof. Despite his rejection of natural theology, Barth developed an empty theology which ignores Scripture as revelation of God and embraced a theology of feeling of F. Schleiermacher's principle of Christian theology (Gulley, 2003; Canale, 2005).

The second question asked states, if God's revelation is only through the person of Jesus Christ, how did God reveal himself before the time of the incarnation? Barth's theology of encounter revelation is based on the transcendent idea of God. Therefore, humanity can know God only through a personal encounter with Jesus Christ because the human mind cannot know God. Barth's idea does not explicitly explain how Jesus was encountered before incarnation and how could a sinful mind which has nothing to do with the divine (as he claims) reach Jesus who was yet to be human? This is a paradox that Barth overlooked in his views. Hebrew 1:1, 2 says "God, who at various times and in various ways spoke in time past to the fathers by the prophets, has in these last days spoken to us by His Son, whom He has appointed heir of all things, through whom also He made the worlds." These texts inform that before incarnation, humanity had access to know God throng oral and written records of the Prophets. Through revelation, God communicated with the prophets and the prophets proclaimed the message and recorded the inspired writings "Scripture" of which humanity was able to know God and come to the saving relationship. This fact is illustrated in the case of Prophet Nathan and David in II Samuel 12:1-13. This fact reveals that the use of scriptural analogy was overlooked in Bath's theology.

Moreover, in some cases, God used general revelation to confirm his majesty so that humanity may know him better as in the case of Job 38-42. From this biblical fact, Barth's theology lacks harmony with the revelation that comes through natural world. This shows that Barth's encounter revelation is limited to a narrow view of Scripture. It 
does not consider systematic theology which is based on a unified biblical canon (Peckham, 2017). Affirming Biblical wholistic revelation, Gulley (2003), referring to John 3:16 concludes that "God reaches out through general and particular revelations to allow every person to be saved" (p. 224).

Moreover, Encounter revelation rejects human reason to the extent that man cannot know God apart from Jesus Christ. Though the statement may seem innocent, Barth's theology suggests infusion which has nothing to do with human conscience. On the contrary, Scripture reveals that the creation story is the initial point of knowing God, whereas the universe and human existence affirm that there is a supernatural designer. Focusing on the creation of man, the Imago Dei in humanity was not totally destroyed after the fall, for Scripture declares that God's natural laws illuminate human conscience and therefore human beings are able to know God the creator. Romans 1:18-20 declares that;

for the wrath of God is revealed from heaven against all ungodliness and unrighteousness of men, who suppress the truth in unrighteousness, because what may be known of God is manifest in them, for God has shown it to them. For since the creation of the world His invisible attributes are clearly seen, being understood by the things that are made, even His eternal power and Godhead, so that they are without excuse.

This passage informs that God has revealed himself through creation, for the necessary knowledge of God is revealed in his attributes and no one can claim to be ignorant of His existence. Proclamation of the merciful God and the conscience led several heathen individuals to accept God the creator. Among them is Ruth the Moabite (Ruth 1:16, 17), and the king and the people of Nineveh (Jonah 3: 59). Claiming that these people came to know God from the encounter revelation is incorrect. In this case, knowing God is a broader phenomenon than just an encounter revelation.

\section{Summary and Conclusion}

Karl Barth's theology was characterized by the passion of defending Christian theology against the liberal approach of studying Scriptures. He challenged his former professors, who advocated human reason in studying the Scriptures to restore the reformation mind in studying the Scripture and to trace back the Orthodoxy principle which in turn coined his theology 'neo-orthodoxy.' This theology rejected natural theology and liberalism. He reasoned that they do not lead to the knowledge of God and brought in encounter revelation as the alternative.

It is evident that Barth's theology is centered in Christology of the Pauline letter to the Romans which is reflected in his Der Römerbrief and Church Dogmatics. Barth's view claims that man cannot know God apart from God's self-revelation through the person of Jesus Christ, and that Scripture is not the word of God but a witness to the word of God (Jesus Christ). From this idea, he developed an encounter revelation which claims that humanity can know God only through encounter experience with Jesus Christ. This paper holds that encounter revelation of Karl Barth is not the only way of knowing God because God reveals himself in both general (universal) and special (particular) revelations. Though God reveals himself fully through the person of Jesus Christ, he also reveals himself in words and acts, through other channels. It is therefore recommended that studying revelation should not be confined in New Testament experience but rather a unified biblical canon that accommodates all humanity of all ages.

\section{Reference}

Barth, Karl. (1957). Church Dogmatics 2 vols. (G.W. Bromiley et al., Trans). Edinburgh: T. and T. Clark.

Barth, Karl. (1976). Epistle to the Romans, (E. C. Hoskyns, Trans.). London: Oxford University Press.

Barth, Karl. (1933). The Epistle to the Romans. (Edwyn C. Hoskyns,Trans.). New York: Oxford University Press.

Barth, Karl. (1939). The Knowledge of God and the Service of God according to the Teaching of the Reformation, (J. L. M. Haire and Ian Henderson, Trans.). New York: Scribner.

Barth, Karl. (1964). The Humanity of God. London: Oxford University. 
Barth, Karl. (1856). The Word of God and the Word of Man. (Douglas Horton, Trans.). New York: Harper and Row.

Barth, Karl (1960). Church Dogmatic trans, Vol. 1.

G.T. Thomas (Edinburgh: T\&T Clark.

"Barth, Karl." Encyclopedia Britannica. Encyclopedia Britannica Ultimate Reference Suite. Chicago: Encyclopedia Britannica, 2010.

Canale, Fernando. (2005). The Cognitive Principle of Christian Theology: A Hermeneutical Study of the Revelation and Inspiration of the Bible. North Charleston: CreateSpace.

Dederen, Raoul. (Ed.). (2000). Handbook of Seventhday Adventist Theology. Hagerstown: Review and Herald Publishing Association.

Dreyer, Wim A.. (2017). "Karl Barth's Römerbrief: A turning point in Protestant Theology". Studia Historiae Ecclesiasticae, 43(3), 1-18. https://dx.doi.org /10.17159/2412-4265/3183.

Erickson, Millard. (2013). Christian Theology: Third Edition. Grand Rapids, MI:

Baker Academic.

Grudem, Wayne. (1994). Systematic Theology: An Introduction to Bible Doctrine. Grand Rapids, MI: Zondervan.

Gulley, Norman R. (2003). Systematic Theology: Prolegomena. Berrien Springs, MI: Andrews University Press.
Hardy, D. W. (2005). "Karl Barth." In The Modern Theologians, 21-42. Oxford: Blackwell Publishing.

Holmes, Austin. (2018). "Encountering Christ: Karl Barth and Mysticism," Lumen et Vita 8:2 27-39 accessed September 16 2019, DOI: 10.6017/LV.v8i2.10508.

Hutabarat, Reymand M. (June 2015) "Exploring Karl Barth's View on the Image of God." International Journal of Philosophy and Theology, 3(1), DOI:10.15640/ijpt.v3n1a17.

Marbaniang, Domenic. (2019). Karl Barth and Emil Brunner on Revelation. https://www.researchgate.net/publication/33 0958670.

McCormack, Bruce, L. Karl Barth's Critically Realistic Dialectical Theology. Oxford: Oxford University Press, 1997.

Mueller, David L. (1972). Karl Barth. Texas: Word Books, Publisher.

Peckham, John C. (Spring 2017). "The Rationale for Canonical Theology: An approach to Systematic Theology after Modernism" Andrews University Seminary Studies 55(1), 83-105.

Smith, David L. (1992). A Handbook of Contemporary Theology: Tracing Trends and Discerning Directions in today's Theological Landscape. Grand Rapids, MI: BakerBook 